Check for updates

Cite this: RSC Adv., 2017, 7, 44154

Received 20th July 2017

Accepted 5th September 2017

DOI: $10.1039 / c 7 r a 08032 h$

rsc.li/rsc-advances

\section{Isochondodendrine and 2'-norcocsuline: additional alkaloids from Triclisia subcordata induce cytotoxicity and apoptosis in ovarian cancer cell linestt:}

\author{
Fidelia ljeoma Uche, (D) ab Mohammed N. Abed, ${ }^{a}$ Marwan I. Abdullah, ${ }^{a}$ \\ Falko P. Drijfhout, ${ }^{\mathrm{C}}$ James McCullagh, ${ }^{\mathrm{d}}$ Timothy W. D. Claridge, (iD d Alan Richardson ${ }^{\mathrm{a}}$ \\ and Wen-Wu Li (iD *a
}

Triclisia subcordata Oliv (Menispermeaceae) is used in herbal medicine for the treatment of cancer and other diseases in Africa. This study aims to isolate minor alkaloids present in this plant and assay their cytotoxic activities. Isochondodendrine and 2 '-norcocsuline as two minor alkaloids together with the abundant cycleanine were isolated and identified by mass spectrometry and NMR spectroscopy. Both isochondodendrine and $2^{\prime}$-norcocsuline exhibited in vitro cytotoxicity in four ovarian cancer cell lines (A2780, IGROV-1, OVCAR-8, and OVCAR-4) with $\mathrm{IC}_{50}$ ranges of 3.5-17 $\mu \mathrm{M}$ and $0.8-6.2 \mu \mathrm{M}$ respectively. These alkaloids showed mostly slightly weaker potencies when tested using normal human ovarian epithelial cells, $I C_{50}=10.5 \pm 1.2 \mu \mathrm{M}$ and $8.0 \pm 0.2 \mu \mathrm{M}$ for isochondodendrine and 2 '-norcocsuline, respectively. The alkaloids induced apoptosis in ovarian cancer cells because they activated caspases 3/7, induced cleavage of PARP, increased the subG ${ }_{1}$ population in cell cycle analysis and increased Annexin $\mathrm{V} /$ propidium iodide staining. These observations suggest that isochondodendrine and $2^{\prime}$-norcocsuline contributing to the cytotoxic activity of $T$. subcordata may be suitable starting points for the future development of novel therapeutics to treat ovarian cancer.

\section{Introduction}

Cancer is among the most life-threatening diseases globally. Ovarian cancer is one of the most difficult cancers to effectively treat because of the development of resistance to available chemotherapeutic agents such as cisplatin and paclitaxel, therefore alternative therapeutics with novel mechanisms of action are urgently needed. Natural products and traditional medicines have been recognized for their major applications in the identification of drug leads and drugs for the treatment of many diseases including ovarian cancer. ${ }^{1-4}$ Numerous phytochemicals and their semi-synthetic derivatives have been approved as anticancer drugs including the well-known paclitaxel, irinotecan, and toptecan. ${ }^{1}$ Many others are currently being evaluated in clinical and preclinical studies. ${ }^{3}$ Because of their

Institute for Science and Technology in Medicine, Keele University, Stoke-on-Trent, ST4 7QB, UK. E-mail: w.li@keele.ac.uk; Tel: +44 (0)1782 674382

${ }^{b}$ Faculty of Pharmaceutical Sciences, University of Port Harcourt, Nigeria ${ }^{c}$ Chemical Sciences Research Centre, Keele University, Staffordshire, ST5 5BG, UK ${ }^{d}$ Chemical Research Laboratory, University of Oxford, Oxford, OX1 3TA, UK

$\dagger$ This study is presented at the 5th International Conference on the Mechanism of Action of Nutraceuticals, Aberdeen, UK.

\$ Electronic supplementary information (ESI) available. See DOI: 10.1039/c7ra08032h diversity in both their chemical structure and mechanisms of action, searching for novel drugs from medicinal plants is still a viable and promising approach..$^{1,5}$

Triclisia subcordata Oliv (Menispermeaceae) is an African medicinal plant. It is used for the treatment of breast cancer in Nigeria. ${ }^{6}$ T. subcordata has been reported to possess cytotoxic, ${ }^{7,8}$ anti-ulcer, ${ }^{9}$ antihistamine, and antimicrobial activities. ${ }^{10}$ Previous reports have identified some of the pharmacologically active components of $T$. subcordata including bisbenzylisoquinoline (BBIQ) alkaloids, tricordatine, ${ }^{11}$ fangchinoline, ${ }^{12}$ and tetrandrine. ${ }^{13}$ The BBIQ alkaloids are a large group of plantderived natural products demonstrating a plethora of biological activities. ${ }^{14}$ For example, tetrandrine, originally isolated from a Chinese medicinal plant - Stephania tetrandra S Moore (Fen-Fang-Ji), inhibits cancer cell proliferation via apoptosis induction, angiogenesis, migration and invasion; reverses multi-drug resistance; and enhances radiation sensitization. ${ }^{15,16}$ We previously isolated and identified a major BBIQ alkaloidcycleanine from $T$. subcordata which showed in vitro antiovarian cancer activity via bioassay guided fractionation. ${ }^{7,8}$

This study focused on isolation and structural identification of additional bioactive compounds of $T$. subcordata and evaluation of their in vitro cytotoxicity in ovarian cell lines by measuring their activity in cell growth and viability assays. ${ }^{17} \mathrm{~A}$ 
panel of assays were used to confirm that the compounds induced apoptosis, including measurement of caspase 3/7 activity, assessing poly(ADP-ribose) polymerase (PARP) cleavage, Annexin V and propidium iodide (PI) staining. The results demonstrate that isochondodendrine and $2^{\prime}$-norcocsuline are likely to contribute to the cytotoxic effects of T. subcordata extracts.

\section{Results}

\section{Isolation and identification of isochondodendrine and 2 '-norcocsuline}

Three alkaloids were extracted, purified and isolated from $T$. subcordata (Fig. S1 and S2 $\$$ ), which showed positive with the
Dragendorff's assay. The purity of each alkaloid was more than 95\%. Their chemical structures (Fig. 1) were identified as cycleanine (1), isochondodendrine (2) (Fig. S3, S4, Tables S1 and S2 $\$$ ) and 2 -norcocsuline (3) (Tables S3 and S4 $\$$ ) on the basis of spectroscopic data including electrospray ionization mass spectrometry (ESI-MS), ${ }^{1} \mathrm{H}$ NMR and ${ }^{13} \mathrm{C}$ NMR spectroscopic analysis in comparison with their spectroscopic data in the literature. ${ }^{18,19}{ }^{1} \mathrm{H}$ NMR and ${ }^{13} \mathrm{C}$ NMR data of the TFA salt of $2^{\prime}$ norcocsuline exhibited slight difference from those of its free base, $2^{\prime}$-norcocsuline. After conversion of its TFA salt to its base form, the observed ${ }^{1} \mathrm{H} \mathrm{NMR}$ and ${ }^{13} \mathrm{C}$ NMR of $2^{\prime}$-norcocsuline were similar and comparable to the literature data for $2^{\prime}$-norcocsuline (Tables S3 and S4 $\$$ ). ${ }^{19}$ Such effect on chemical shifts by TFA was also observed for cycleanine. ${ }^{7}$
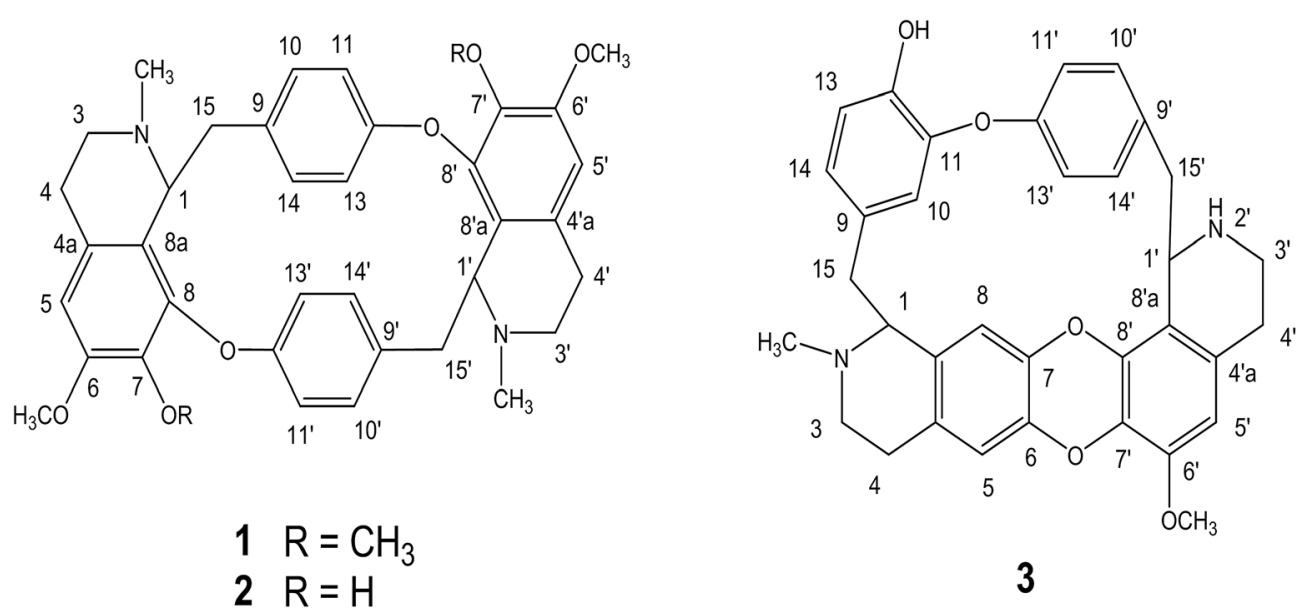

Fig. 1 Chemical structures of cycleanine (1), isochondodendrine (2) and $2^{\prime}$-norcocsuline (3) from T. subcordata.

A)

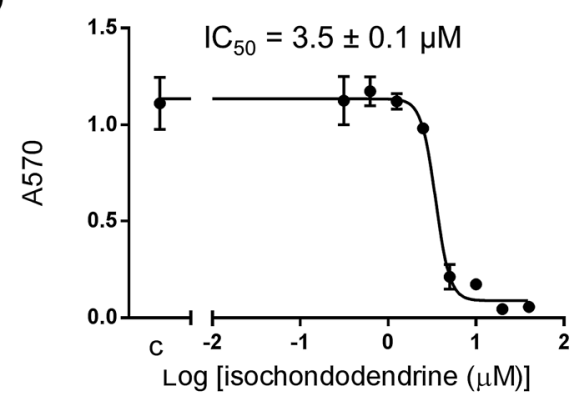

C)

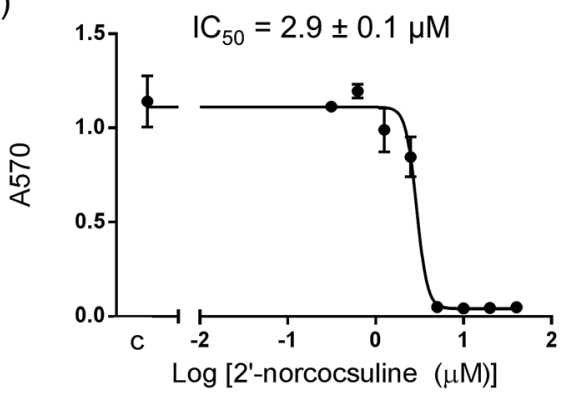

B)

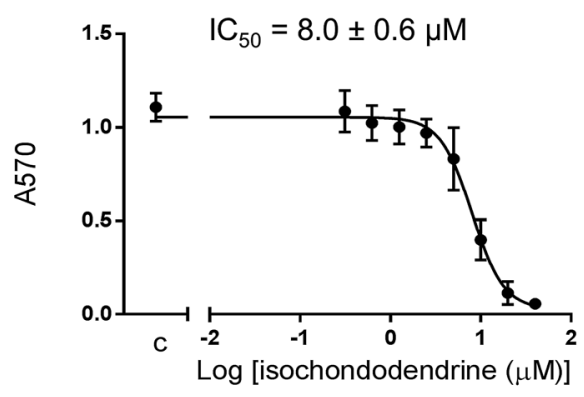

D)

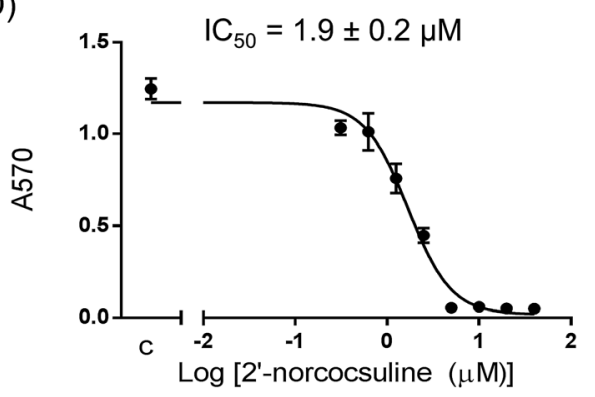

Fig. 2 Concentration versus response curves of isochondodendrine (2) in A2780 (A) and OVCAR-8 (B) cells, and 2' -norcocsuline (3) in A2780 (C) and OVCAR-8 (D) cells after treatment for $72 \mathrm{~h}$. C on the $x$-axis represents the medium control. The mean values of their $I C_{50}$ are expressed as mean \pm standard error of the mean (SEM) $(n=5)$. 


\section{Cell growth assays of isochondodendrine and $2^{\prime}$-norcocsuline}

The activity of isochondodendrine and $2^{\prime}$-norcocsuline isolated from $T$. subcordata were determined in cell growth assays using different ovarian cancer cell lines (A2780, IGROV-1, OVCAR-8, and OVCAR-4) (Fig. 2). The compounds inhibited growth of the cultures with $\mathrm{IC}_{50}$ range of $3.5-17 \mu \mathrm{M}$ (isochondodendrine) and $0.8-6.2 \mu \mathrm{M}\left(2^{\prime}\right.$-norcocsuline) respectively. Carboplatin and paclitaxel were used as positive controls (Table 1). For comparison, the $\mathrm{IC}_{50}$ in cell growth assays using normal human ovarian epithelial (HOE) cells were $10.5 \pm 1.2 \mu \mathrm{M}$ and $8.0 \pm$ $0.2 \mu \mathrm{M}$ for isochondodendrine and 2 '-norcocsuline, respectively. The compounds showed somewhat greater potencies for the cancer cells compared to normal cells (selectivity index (SI), Table 1).

The trypan blue exclusion method was employed to distinguish cytotoxic and cytostatic effects of the compounds in the cell growth assays. The cell viability of A2780, IGROV-1, OVCAR8 , and OVCAR- 4 cells was reduced in a concentration-dependent manner after $48 \mathrm{~h}$ treatment by isochondodendrine and 2 -norcocsuline at the concentration of 5, 10 and $20 \mu \mathrm{M}$ as well as by the positive control carboplatin, when the four cancer cell lines were exposed to the BBIQ alkaloids for $48 \mathrm{~h}$ (Fig. 3).

\section{Apoptosis}

To evaluate whether the decrease in viability caused by isochondodendrine (2) and 2'-norcocsuline (3) was due to increased apoptosis, the activation of caspase $3 / 7$ by these compounds was evaluated. Isochondodendrine and 2 '-norcocsuline caused a significant increase in caspase activity in A2780, IGROV-1, and OVCAR-8 cells (Fig. 4).

To confirm that the compounds induced apoptosis, morphological changes, cleavage of poly(ADP-ribose) polymerase (PARP), and flow cytometry studies were performed. OVCAR-8 was chosen for these studies because it was regarded as a likely high-grade serous ovarian cancer cell line. ${ }^{20}$ Morphological alterations of OVCAR-8 cells treated with

Table 1 The potency of isochondodendrine (2) and 2'-norcocsuline (3) from T. subcordata in A2780, IGROV-1, OVCAR-8, and OVCAR-4 cell growth assays. The $\mathrm{IC}_{50}$ data are expressed as mean $\pm \mathrm{SEM}(n=5)$. Carboplatin and paclitaxel served as positive control. N.D. represents not determined

\begin{tabular}{|c|c|c|c|c|c|}
\hline \multirow[b]{2}{*}{ Sample and SI } & \multicolumn{5}{|c|}{ Cell lines/IC $\mathrm{IC}_{50} \pm \operatorname{SEM}(\mu \mathrm{M})$} \\
\hline & A2780 & IGROV-1 & OVCAR-8 & OVCAR-4 & HOE \\
\hline SI against HOE & 3.0 & 1.1 & 1.3 & $<1$ & \\
\hline 2'-Norcocsuline (3) & $2.9 \pm 0.1$ & $0.8 \pm 0.1$ & $1.9 \pm 0.2$ & $6.2 \pm 0.5$ & $8.0 \pm 0.2$ \\
\hline SI & 2.8 & 10 & 4.2 & 1.3 & \\
\hline
\end{tabular}

A)

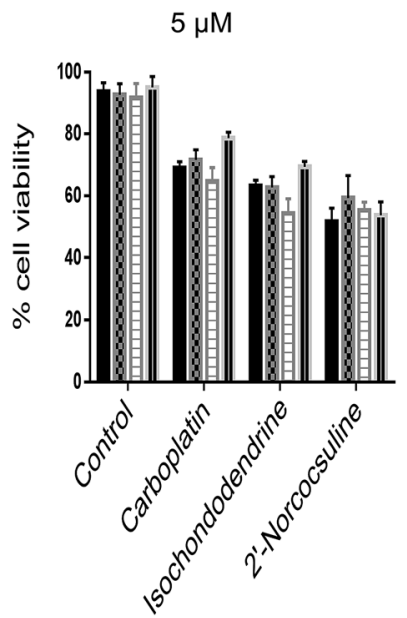

B)

$10 \mu \mathrm{M}$

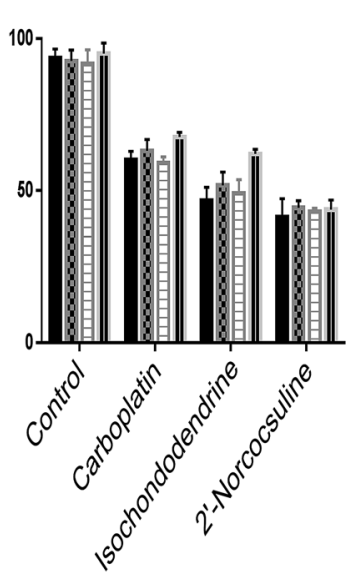

C)

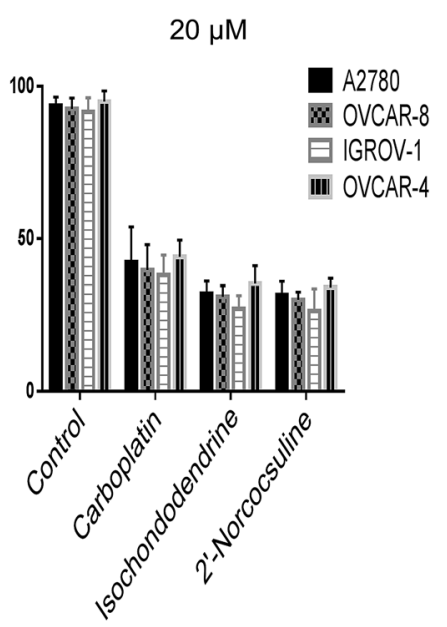

Fig. 3 Effects of isochondodendrine (2) and 2'-norcocsuline (3) on the viability of ovarian cancer cells. The percentages of viable cells of A2780, IGROV-1, OVCAR-8, and OVCAR-4 cell lines, $48 \mathrm{~h}$ post-treatment with medium ("control"), carboplatin (which served as a positive control), isochondodendrine, or $2^{\prime}$-norcocsuline at $5 \mu \mathrm{M}(\mathrm{A}), 10 \mu \mathrm{M}(\mathrm{B})$ and $20 \mu \mathrm{M}(\mathrm{C})$ were determined by measuring trypan blue exclusion. The results are expressed as the percentage of the viability of cells in each sample and are expressed as mean $\pm \operatorname{SEM}(n=3)$. The cell viability of each cell line was significantly decreased in the treatment group, compared to control $(P<0.05$, one-way ANOVA with Dunnett's multiple comparison post hoc test). 
A)

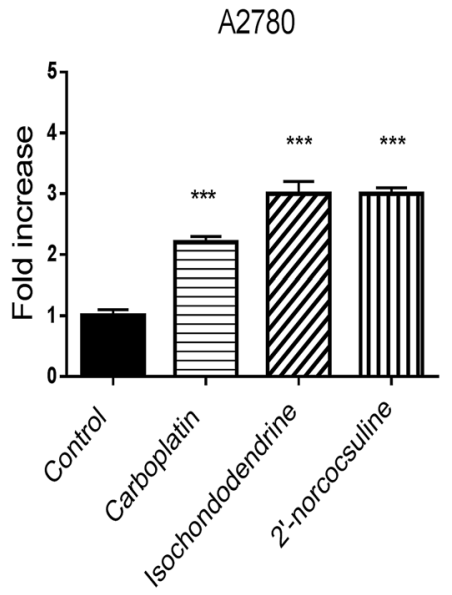

B)

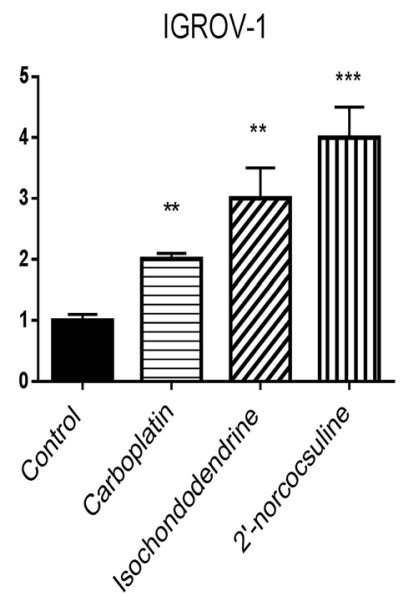

C)

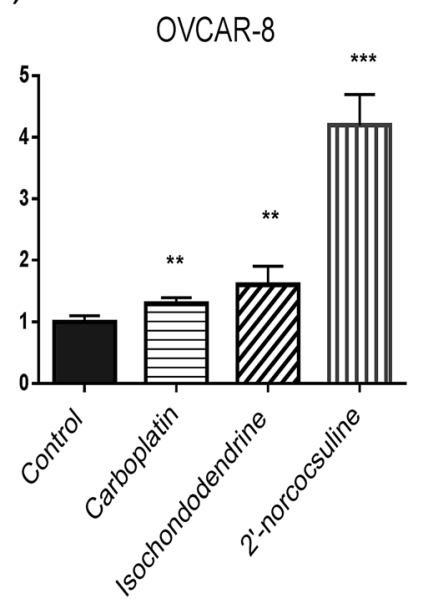

Fig. 4 Effects on caspase 3/7 activity in ovarian cancer cells by isochondodendrine and $2^{\prime}$-norcocsuline. Enzymatic activities of caspase 3/7 after $48 \mathrm{~h}$ treatment of A2780 (A), IGROV-1 (B) and OVCAR-8 (C) cells with medium as control, carboplatin, isochondodendrine and 2' -norcocsuline. The caspase activity is expressed as fold increase relative to control cells treated with drug solvent (mean $\pm \mathrm{SEM} ; n=6)$. This was analyzed using one-way ANOVA with Dunnett's comparison post hoc test, $* P<0.05 ; * * P<0.001 ; * * * P<0.0001$.

isochondodendrine and 2 -norcocsuline showed membrane blebbing, rounding up and cell detachment consistent with apoptosis (Fig. S5 ). PARP cleavage, a marker of apoptosis, was assessed by immunoblotting. Exposure of OVCAR-8 cells to carboplatin, isochondodendrine and 2 '-norcocsuline resulted in significant PARP cleavage (Fig. 5).

To further quantify the percentage of apoptotic cells after treatment of these alkaloids, the OVCAR- 8 cells were stained by Annexin V and PI and analysed by flow cytometry (Fig. 6). Treatment of OVCAR-8 cells with carboplatin, isochondodendrine or $2^{\prime}$-norcocsuline for $48 \mathrm{~h}$ cells caused a significant increase of the population of both early and late apoptotic cells (Fig. 6). 2'-Norcocsuline was the strongest inducer among them.

\section{Cell cycle analysis}

To assess whether isochondodendrine and 2 -norcocsuline also affected cell cycle progression, OVCAR-8 cells were analysed by
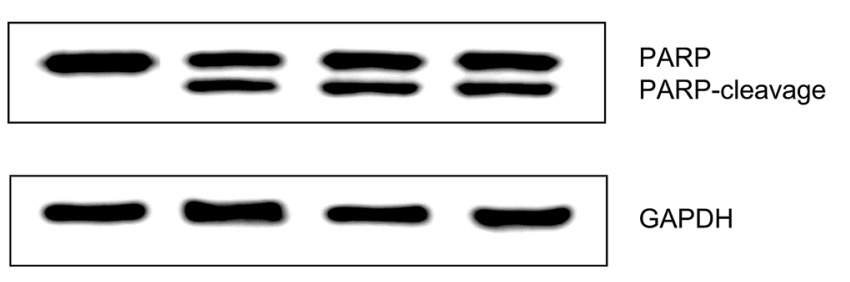

GAPDH

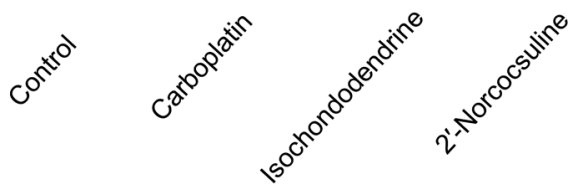

Fig. 5 Western blot analysis of PARP cleavage in OVCAR- 8 cells. Treatment of OVCAR- 8 cells after $48 \mathrm{~h}$ with carboplatin, isochondodendrine and $2^{\prime}$-norcocsuline caused cleavage of PARP. GAPDH was used as a loading control. flow cytometry after staining cells with PI. However, the most striking effect was the increase in OVCAR-8 cells in subG population after exposure to isochondodendrine and $2^{\prime}$-norcocsuline for $48 \mathrm{~h}$ compared to negative control (Fig. 7). Carboplatin, used as positive control known to induce apoptosis, also caused an increase in the subG ${ }_{1}$ population.

\section{Discussion}

The BBIQ alkaloids have been shown to possess a range of biological activities, including cytotoxic, ${ }^{8,19,21,22}$ inhibition of histamine release, ${ }^{23}$ antiplasmodial, ${ }^{24}$ and anti-leishmanial and anti-trypanosomal effects. ${ }^{25}$ A BBIQ alkaloid - cycleanine has been isolated from $T$. subcordata and shown to exert cytotoxicity through induction of apoptosis. ${ }^{7,8}$

In this study two additional minor BBIQ alkaloidsisochondodendrine (2) and 2'-norcocsuline (3) (Fig. 1), besides the major cycleanine (1) from T. subcordata, were isolated and characterized. The analytical data (ESI-MS and NMR) were consistent with literature data for isochondodendrine ${ }^{18}$ and $2^{\prime}$ norcocsuline. ${ }^{19}$ To our surprise, the previously reported tricordatine ${ }^{11}$ fangchinoline ${ }^{12}$ tetrandrine ${ }^{13}$ in 1970 s from this plant were not found by us in the present study. Those compounds might be the trace components in our extract, present as small peaks on HPLC (Fig. S2\$), or this discrepancy might be due to the collection of plant materials from different locations and/or in different seasons. Nevertheless, isochondodendrine and $2^{\prime}$-norcocsuline demonstrated antiovarian cancer activity with potencies comparable to those we have previously observed with cycleanine and tetrandrine., Both alkaloids showed more sensitivity to A2780, IGROV-1 and OVCAR-8 cells than OVCAR-4 cells after treatment for $72 \mathrm{~h}$ using SRB assay (Fig. 2, Table 1). Although the pharmacokinetics of these compounds remains to be defined, it is encouraging to note that isochondodendrine showed similar potency to the 


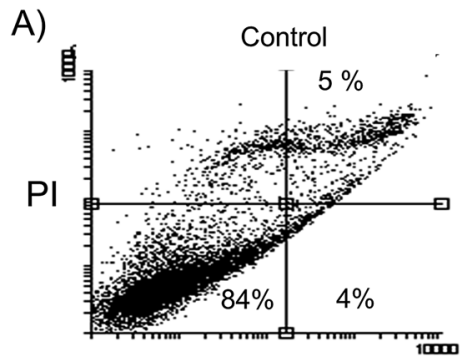

C)

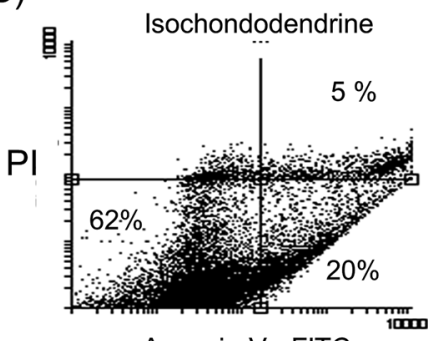

Annexin V - FITC
B)

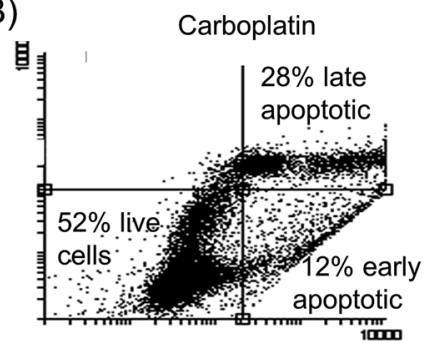

D)

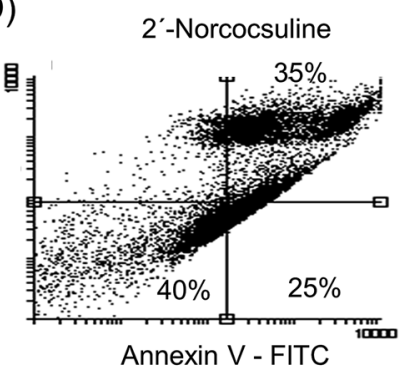

E)

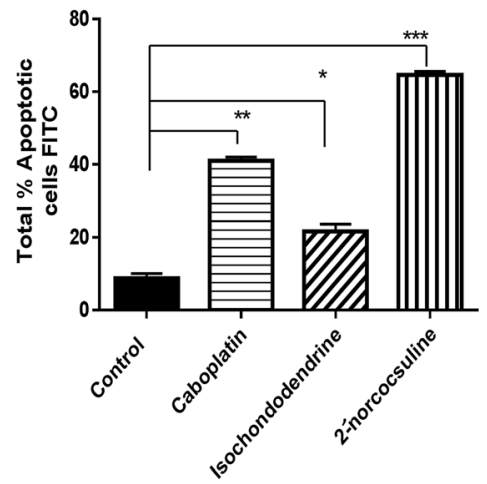

Fig. 6 Flow cytometry analysis of apoptotic effects of isochondodendrine and 2'-norcocsuline on OVCAR-8 cells. The scatter dot plots indicating the percentage of live (Annexin $\mathrm{V}$ negative, PI negative), early (Annexin $\mathrm{V}$ positive, PI negative) and late (Annexin $\mathrm{V}$ positive, PI positive) apoptotic cells after treatment with medium (control) (A), carboplatin (B), isochondodendrine (C), and $2^{\prime}$-norcocsuline (D) for $48 \mathrm{~h}$ by using Annexin $\vee \&$ PI assay. The percentages of the total apoptotic cells induced by carboplatin, isochondodendrine, and $2^{\prime}$-norcocsuline were significant compared to control (E) (one-way ANOVA with Dunnett's comparison post hoc test, $* P<0.05$; ** $P<0.001$; ***P<0.0001).

clinically used drug carboplatin, and 2'-norcocsuline was more potent than carboplatin in all four cancer cell lines. Previously, 2'-norcocsuline, isolated from Anisocycla grandidieri, showed cytotoxicity $\left(\mathrm{IC}_{50}, 2.7 \mu \mathrm{M}\right)$ against A2780 ovarian cancer cells, ${ }^{19}$ in agreement with our findings. It seemed that the increase of the hydrophilicity (more hydroxyl or amine groups in $\mathbf{2}$ and 3 than 1) increased the potency of these alkaloids.
The cell viability was further measured with trypan blue, which indicated that the two alkaloids (2 and 3) caused concentration-dependent cell deaths in the four cancer cell lines after $48 \mathrm{~h}$ treatment (Fig. 3). Further experiments were carried out for the detection of markers of apoptosis such as caspases $3 / 7$ and cleavage of PARP, ${ }^{7,26}$ and effects on cell cycles by these alkaloids after treatment for $48 \mathrm{~h}$. Both alkaloids and carboplatin increased caspase 3/7 activity significantly (Fig. 4),

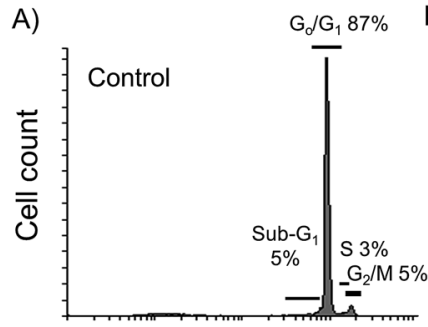

B)
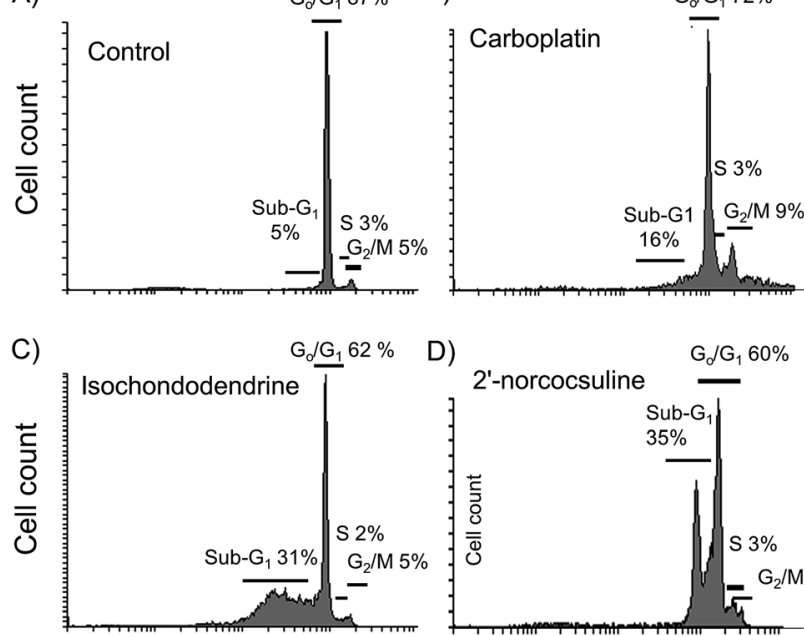

E)

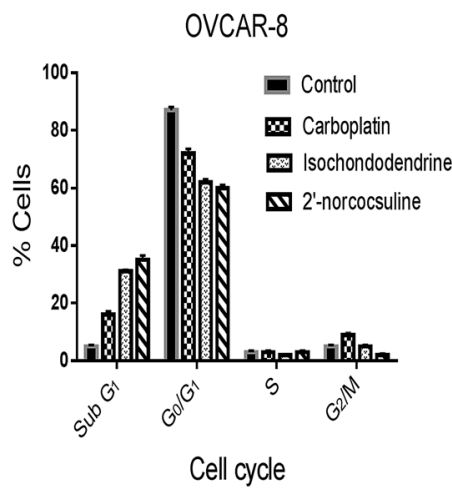

Fluorescence intensity

Fig. 7 Effects of isochondodendrine and 2'-norcocsuline on cell cycle of OVCAR-8 cells. The effects of medium (control) (A), carboplatin (B), isochondodendrine (C), and $2^{\prime}$-norcocsuline (D) on the OVCAR- 8 cell cycle were analyzed by use of flow cytometry. The percentage of subG ${ }_{1}$ phase (apoptotic cells) of the OVCAR- 8 cell cycle was significantly increased compared to cells exposed to medium (E). While $\mathrm{G}_{0} / \mathrm{G}_{1} \mathrm{phase}$ (live cells) decreased significantly compared to negative control $(P<0.0001$, one-way ANOVA Dunnett's comparison post hoc test, $n=5$ independent experiments). 
induced PARP cleavage (Fig. 5) and the externalization of phosphatidylserine at the cell surface (Fig. 6) in A2780, IGROV-1 and/or OVCAR-8 cell lines. It is known that caspase family proteins are the executioners of apoptosis. Caspase cascades are activated either through intrinsic (mitochondrial) pathwayinduced initiator caspase-9 or through extrinsic (death receptor) apoptotic pathway-induced initiator caspase-8. ${ }^{26}$ Both pathways eventually lead to the activation of caspase 3 and 7 , which cause the cleavage of structural and functional proteins such as PARP as demonstrated above. The cell fraction of sub$\mathrm{G}_{1}$, a characteristic indicator of apoptosis, caused by isochondodendrine and 2 -norcocsuline was increased in ovarian cancer cells (Fig. 7), which demonstrated the induction of apoptosis. ${ }^{7,27}$ Taken together, this provided robust evidence that these compounds induced apoptosis. It is also noteworthy that other alkaloids which were isolated from the same plant species, cycleanine and tetrandrine, ${ }^{7,8,13}$ also induced apoptosis.

Important questions such as what are the exact biological targets of BBIQ alkaloids in cells causing downstream apoptosis and how they regulate apoptosis and cell cycle remain to be answered. BBIQ alkaloids such as tetrandrine have been shown to specifically bind a parallel G-quadruplex in vitro by electrospray ionization mass spectrometry, ${ }^{\mathbf{2 8 , 2 9}}$ suggesting that the mechanism of action of those compounds might include interaction with DNA. However, tetrandrine and its derivatives have also been shown to inhibit ATP-dependent efflux pump P-glycoprotein activity and reverse the multidrug resistance in human cancer cells. ${ }^{\mathbf{3 0}, 31}$ This suggests that BBIQ alkaloids could induce their biological effects through a variety of different pathways. Further work will be necessary and important to identify the precise biological targets of these BBIQ alkaloids in order to understand their mechanisms of action using cellular thermal shift assay ${ }^{32}$ and/or a chemoproteomics approach. ${ }^{33}$ It also raises the possibility that these compounds in particular $2^{\prime}$ norcocsuline (3) may be useful as starting points to develop novel therapeutics to treat ovarian cancer if their mechanisms are known. It is likely that modification (e.g. replacement of $\mathrm{H}-5$ in 1 and 2 by halogen atoms ${ }^{31}$ or other functional groups) and optimization of these compounds will be necessary to obtain structure activity relationships and improve their potency, selectivity and pharmacokinetics. This work is ongoing in our laboratory and due to report.

\section{Experimental}

\section{General}

${ }^{1} \mathrm{H}$ NMR (400 or $500 \mathrm{MHz}$ ), ${ }^{13} \mathrm{C}$ NMR (125 MHz), and 2D-NMR (COSY, HMQC and HMBC) spectra were obtained on a Bruker 400 or $500 \mathrm{MHz}$ instruments. Chemical shifts were reported in $\delta$ (ppm) using the solvents $\left(\mathrm{CDCl}_{3}+\mathrm{CD}_{3} \mathrm{OD}\right)$ standard and coupling constants $(J)$ were measured in hertz. The highresolution mass spectra of the alkaloids were measured on a Thermo Scientific Q-Exactive Orbitrap mass spectrometer system using a HESI II electrospray ion source. Silica gel (Sigma-Aldrich) was used as an adsorbent for flash column chromatography. Dragendorff's reagents were purchased from Sigma-Aldrich.

\section{Plant material}

T. subcordata root was collected from Orlu LGA, Imo state, Nigeria. The plant material was identified by a taxonomist, H. D. Onyeachusim. The voucher specimen (Voucher number: UUH1817) was deposited at the herbarium of University of Uyo, Akwa Ibom state, Nigeria. The root bark of the plant part was made into powder and stored for solvent extraction.

\section{Extraction of T. subcordata}

The $1.8 \mathrm{~kg}$ powdered root was extracted thrice by maceration with $8 \mathrm{~L}$ of $5 \%$ acetic acid for $48 \mathrm{~h}$ (Fig. S1 $)$ ). The extracts were combined and concentrated with a rotary evaporator. The crude extract was subjected to alkaloid extraction, by alkalinization with ammonium hydroxide $\left(\mathrm{NH}_{4} \mathrm{OH}\right.$; $\left.\mathrm{pH} 9-10\right)$ and subsequent partition with chloroform to yield total alkaloid extract $(22.6 \mathrm{~g})$. Three pure alkaloids, cycleanine (1: 1.1\%), isochondodendrine (2: $0.1 \%$ ) and $2^{\prime}$-norcocsuline (3: $0.01 \%$ ) (Fig. 1 and S2 $\$$ ) were isolated by using combined methods of silica gel column chromatography, recrystallization and high performance liquid chromatography (HPLC) procedure as previously described. ${ }^{7}$

Isochondodendrine (2), white powder, ${ }^{1} \mathrm{H}$ and ${ }^{13} \mathrm{C}$ NMR $\left(\mathrm{CDCl}_{3}+\mathrm{CD}_{3} \mathrm{OD}(1: 1)\right)$ (Fig. S3, S4, Tables S1 and S2 $)$. Positive HR-ESI-MS, $m / z: 595.2807$ (calcd mass for $\mathrm{C}_{36} \mathrm{H}_{39} \mathrm{~N}_{2} \mathrm{O}_{6},[\mathrm{M}+\mathrm{H}]^{+}$, 595.2808).

Trifluoroacetic acid (TFA) salt of $2^{\prime}$-norcocsuline $(3),{ }^{1} \mathrm{H}$ and ${ }^{13} \mathrm{C}$ NMR $\left(\mathrm{CDCl}_{3}+\mathrm{CD}_{3} \mathrm{OD}(1: 1)\right)$ see Tables $\mathrm{S} 3$ and S4. + Positive HR-ESI-MS, $m / z: 549.2384$ (calcd mass for $\mathrm{C}_{34} \mathrm{H}_{33} \mathrm{~N}_{2} \mathrm{O}_{5},[\mathrm{M}+\mathrm{H}]^{+}$, 549.2389).

Conversion of TFA salt of $2 '$-norcocsuline (3) to its free base, $2^{\prime}$-norcocsuline - TFA salt was carried out by first alkalinization and subsequent extraction with chloroform to give its free base form. ${ }^{1} \mathrm{H}$ and ${ }^{13} \mathrm{C} \mathrm{NMR}\left(\mathrm{CDCl}_{3}+\mathrm{CD}_{3} \mathrm{OD}(1: 1)\right)$ of free base form 3 are also listed Tables S3 and S4. +

\section{Cell culture}

The normal human ovarian epithelial (HOE) and human ovarian cancer cell lines (A2780, IGROVE-1, OVCAR-8, and OVCAR-4) cells were cultured in RPMI 1640 medium supplemented with $10 \%$ fetal bovine serum (FBS), penicillinstreptomycin (50 $\left.\mathrm{U} \mathrm{mL}^{-1}\right)$, and glutamine $(2 \mathrm{mM})$. All ovarian cancer cell lines were products of American tissue culture collection (ATCC). HOE cells were bought from Applied Biological Materials (ABM) Inc. HOE was originated from normal ovarian epithelium and immortalized using SV40 large T antigen.

\section{Cell growth assay}

Cell growth inhibition assay was performed using sulforhodamine B (SRB) assay to determine the effects of isochondodendrine (2), 2'-norcocsuline (3), carboplatin (0.16-40 $\mu \mathrm{M})$ and control medium on the growth of ovarian cancer cell lines (A2780, IGROV-1, OVCAR-8, and OVCAR-4) and normal HOE cells after treatment for $72 h^{., 34}$ The principle of SRB assay used for the determination of cell density is based on the measurement of live cellular protein content. Briefly, 5000 cells 
(IGROV-1, OVCAR-4, or HOE), and 2000 cells (OVCAR-8 and A2780) in $80 \mu \mathrm{l}$ of growth medium were seeded in a 96-well plate. After $24 \mathrm{~h} 20 \mu \mathrm{l}$ of the two alkaloids and carboplatin dissolved in DMSO (final concentration $0.2 \%$ ) were added. After $72 \mathrm{~h}$ the medium was removed and the cells were fixed with $10 \%$ TCA before being stained with $0.4 \%$ SRB in $1 \%$ acetic acid. After washing with $1 \%$ acetic acid, the protein-dye complexes were dissolved in $10 \mathrm{mM}$ Tris-base solution for OD determination at $570 \mathrm{~nm}$ using a microplate reader. ${ }^{34}$ The $\mathrm{IC}_{50}$ s were determined using GraphPad Prism 6 software.

\section{Cell counting}

The viability of ovarian cancer cells was measured using trypan blue exclusion method before seeding cells and after treatment of A2780, IGROV-1, OVCAR-8, and OVCAR-4 cells (200, 000 cells per $\mathrm{ml}$ ) with alkaloids 2 and $3(5,10$ and $20 \mu \mathrm{M})$ for $48 \mathrm{~h}$ as previously described using a Countess cell counter. ${ }^{7}$

\section{Caspase-Glo 3/7 activity assay}

The effect of isochondodendrine and 2 -norcocsuline on the caspase- $3 / 7$ activities in A2780, IGROV-1, and OVCAR- 8 cells was carried out using assay kits Caspase-Glo 3/7 (Promega Corp., Madison, WI, USA) on a 96-well microplate, as described previously. ${ }^{7}$ Briefly, IGROV-1 and OVCAR-4 (5000 cells per well), A2780 and OVCAR-8 (2000 cells per well) cells were incubated in $80 \mu \mathrm{L}$ growth medium in a 96-well plate for $24 \mathrm{~h}$. Cells were then supplemented with growth medium (control), carboplatin, isochondodendrine and $2^{\prime}$-norcocsuline $(20 \mu \mathrm{M})$ for $48 \mathrm{~h}$. An inverted light microscope was used to capture the morphological images before adding Caspase-Glo 3/7 reagent agents to the cell culture. After incubating at room temperature for $30 \mathrm{~min}$ in the dark, the optical reading was measured at $570 \mathrm{~nm}$.

\section{Western blot assay}

To evaluate apoptosis caused by isochondodendrine and $2^{\prime}$ norcocsuline in OVCAR-8 cells, western blot assay was carried out according to described procedure. ${ }^{7}$ Briefly, 200000 OVCAR8 cells per $\mathrm{ml}$ were seeded in a six-well plate and were treated with isochondodendrine, $2^{\prime}$-norcocsuline, carboplatin $(20 \mu \mathrm{M})$, or medium for $48 \mathrm{~h}$. The cells were collected by trypsinization and lysed. The extracted proteins were resolved on 4-20\% Tris-glycine polyacrylamide gradient gel (Nusep). After electrophoresis, the proteins were transferred to a polyvinylidene fluoride membrane. The membrane was first washed with buffer containing 5\% skimmed milk powder and then probed with antibodies against poly(ADP-ribose) polymerase (PARP) for $16 \mathrm{~h}$ at $4{ }^{\circ} \mathrm{C}$ overnight or glyceraldehyde-3-phosphate dehydrogenase (GAPDH) from mouse $(1: 5000)$ for $1 \mathrm{~h}$ at room temperature. Proteins were visualized using UptiLight HRP chemiluminescent substrate on a FluorChem M system.

\section{Flow cytometry analysis}

The effect on cell cycle of OVCAR-8 cells by isochondodendrine and 2 -norcocsuline using propidium iodide (PI) was assayed according to the published procedures. ${ }^{7}$ Briefly, OVCAR-8 $(1 \times$
$10^{6}$ cells per $\mathrm{ml}$ ) cells after treatment of carboplatin and the two alkaloids $(20 \mu \mathrm{M})$ for $48 \mathrm{~h}$ were trypsinized, fixed with $70 \%$ ethanol and stained with PI. The stained cells were measured by flow cytometry to score the DNA content. The percentages of cells in the $\mathrm{SubG}_{1}, \mathrm{G}_{0} / \mathrm{G}_{1}, \mathrm{~S}$ and $\mathrm{G}_{2} / \mathrm{M}$ cell cycle phases were determined using FLOWING software.

The apoptosis assay using fluorescein isothiocyanate (FITC)conjugated Annexin V to label cell-surface phosphatidylserine of apoptotic cells and PI to label DNA content was also carried out using the procedure described previously. ${ }^{7}$ Briefly, OVCAR-8 cells (300 000 cells per $\mathrm{ml}$ ) after treatment of carboplatin, isochondodendrine and 2 -norcocsuline $(20 \mu \mathrm{M})$ for $48 \mathrm{~h}$ were trypsinized, and stained with Annexin V-FITC dye and PI. The cells were measured by flow cytometry. The percentages of live cells, dead, early and late apoptotic cells were determined using FLOWING software.

\section{Statistical analysis}

The results were presented as mean values \pm SEM. One-way analysis of variance (ANOVA) with Dunnett's (multiple) comparison post hoc test was used for the determination of statistical significance of difference between means. $P$-Values $<0.05$ were considered statistically significant. All analyses were performed using GraphPad Prism software 6.0.

\section{Conclusion}

This study identifies isochondodendrine and $2^{\prime}$-norcocsuline as minor and bioactive constituents of T. subcordata, which serves to further explain the in vitro anti-cancer activity via induction of apoptosis and interference of cell cycle. These results provide a new source of cytotoxic alkaloids and support its traditional use of T. subcordata in cancer treatment.

\section{Conflicts of interest}

There are no conflicts to declare.

\section{Acknowledgements}

We thank Nigerian Education Trust Fund (ETF) and Niger Delta Developement Commission (NDDC) for funding.

\section{References}

1 G. M. Cragg and D. J. Newman, Biochim. Biophys. Acta, 2013, 1830, 3670-3695.

2 D. J. Newman and G. M. Cragg, J. Nat. Prod., 2016, 79, 629661.

3 W. W. Li, O. R. Johnson-Ajinwo and F. I. Uche, Int. J. Cancer Res. Prev., 2016, 9, 81-105.

4 O. R. Johnson-Ajinwo, A. Richardson and W. W. Li, Phytomedicine, 2015, 22, 1-4.

5 A. L. Harvey, R. Edrada-Ebel and R. J. Quinn, Nat. Rev. Drug Discovery, 2015, 14, 111-129.

6 I. T. Gbadamosi and S. M. Erinoso, Afr. J. Pharm. Pharmacol., 2016, 10, 546-564. 
7 F. I. Uche, F. P. Drijfhout, J. McCullagh, A. Richardson and W. W. Li, Phytother. Res., 2016, 30, 1533-1539.

8 F. I. Uche, F. Drijfhout, J. McCullagh, A. Richardson and W. W. Li, Planta Med., 2016, 82, S1-S381.

9 I. U. Asuzu and A. O. Anaga, J. Herbs, Spices Med. Plants, 1996, 45-53.

10 K. A. Abo, I. O. Lawal and A. Ogunkanmi, Afr. J. Pharm. Pharmacol., 2011, 5, 125-131.

11 A. N. Tackie, D. Dwuma-Badu, T. Okarter, J. E. Knapp, D. J. Slatkin and P. L. Schiff Jr, Phytochemistry, 1973, 12, 2509-2511.

12 A. N. Tackie, D. Dwuma-Badu, T. Okarter, J. E. Knapp, D. J. Slatkin and P. L. Schiff Jr, Lloydia, 1974, 37, 1-5.

13 D. Dwuma-Badu, J. S. K. Ayim, A. N. Tackie, J. E. Knapp, D. J. Slatkin and P. L. Schiff Jr, Phytochemistry, 1975, 14, 2524-2545.

14 P. L. Schiff Jr, J. Nat. Prod., 1997, 60, 934-953.

15 T. Liu, X. Liu and W. Li, Oncotarget, 2016, 7, 40800-40815.

16 N. Bhagya and K. R. Chandrashekar, Phytochemistry, 2016, 125, 5-13.

17 F. I. Uche, M. Abed, M. I. Abdullah, F. P. Drijfhout, J. McCullagh, T. W. D. Claridge, A. Richardson and W. W. Li, Biochem. Pharmacol., 2017, 139, 112.

18 B. Kanyinda, R. Vanhaelen-Fastré and M. Vanhaelen, J. Nat. Prod., 1997, 60, 1121-1124.

19 Y. X. Liu, L. Harinantenaina, P. J. Brodie, C. Slebodnick, M. W. Callmander, R. Rakotondrajaona, E. Rakotobe, V. E. Rasamison, K. TenDyke, Y. C. Shen and D. G. I. Kingston, Magn. Reson. Chem., 2013, 51, 574-579.
20 S. Domcke, R. Sinha, D. A. Levine, C. Sander and N. Schultz, Nat. Commun., 2013, 4, 2126.

21 Y. F. Sun and M. Wink, Phytomedicine, 2014, 21, 1110-1119.

22 J. Z. Wang, Q. H. Chen and F. P. Wang, J. Nat. Prod., 2010, 73, 1288-1293.

23 K. Nakamura, S. Tsuchiya, Y. Sugimoto, Y. Sugimura and Y. Yamada, Planta Med., 1992, 58, 505-508.

24 C. K. Angerhofer, H. Guinaudeau, V. Wongpanich, J. M. Pezzuto and G. A. Cordell, J. Nat. Prod., 1999, 62, 59-66.

25 M. del Rayo Camacho, J. D. Phillipson, S. L. Croft, P. Rock, S. J. Marshall and P. L. Schiff Jr, Phytother. Res., 2002, 16, 432-436.

26 S. W. Fesik, Nat. Rev. Cancer, 2005, 5, 876-885.

27 M. Kajstura, H. D. Halicka, J. Pryjma and Z. Darzynkiewicz, Cytometry, Part A, 2007, 71, 125-131.

28 Y. C. Qi, H. Chen, W. Tan, Y. Y. Li, G. Yuan and M. Xu, Rapid Commun. Mass Spectrom., 2015, 29, 1611-1616.

29 N. S. Xu, H. M. Yang, M. Cui, F. R. Song, Z. Q. Liu and S. Y. Liu, J. Mass Spectrom., 2012, 47, 694-700.

30 Z. Cao, M. Wright, J. Cheng, X. Huang, L. Liu, L. Wu and P. Yang, Oncol. Rep., 2014, 32, 1211-1217.

31 H. Sun, X. D. Liu, Q. Liu, F. P. Wang, X. Q. Bao and D. Zhang, J. Asian Nat. Prod. Res., 2015, 17, 638-648.

32 D. M. Molina, R. Jafari, M. Ignatushchenko, T. Seki, E. A. Larsson, C. Dan, L. Sreekumar, Y. H. Cao and P. Nordlund, Science, 2013, 341, 84-87.

33 R. E. Moellering and B. F. Cravatt, Chem. Biol., 2012, 19, 1122.

34 V. Vichai and K. Kirtikara, Nat. Protoc., 2006, 1, 1112-1116. 